\title{
International trade in services: firm-level evidence for Portugal
}

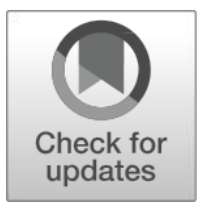

\author{
João Amador ${ }^{1,2} \cdot$ Sónia Cabral ${ }^{1}$ (D) $\cdot$ Birgitte Ringstad ${ }^{2}$
}

Received: 25 June 2018 / Accepted: 21 May 2019 / Published online: 11 July 2019

(C) ISEG - Instituto Superior de Economia e Gestão 2019

\begin{abstract}
This paper adds to the existing firm-level evidence on international trade in nontourism services, using a new Portuguese database merged with balance-sheet data. In accordance with the literature, we find that a small number of firms that both export and import services (two-way traders) with diversified service and geographi- cal portfolios account for a substantial share of trade flows. Compared with one-way traders, two-way traders are larger, older, more productive, more profitable and have a higher share of foreign equity. Considering all margins of firm-level trade and controlling for firms' characteristics, the intensive margins of exports and imports of services are positively related to both productivity and profitability. Regarding the extensive margins, the number of services imported is also positively associated with firms' performance.
\end{abstract}

Keywords International trade ' Services - Trade margins ' Firm-level data

JEL Classification F1 $\cdot$ F14 $\cdot$ L25

Sónia Cabral

scabral@bportugal.pt

João Amador

jamador@bportugal.pt

Birgitte Ringstad

biringstad@gmail.com

1 Banco de Portugal, Lisbon, Portugal

2 Nova School of Business and Economics, Carcavelos, Portugal 